\title{
Exploration of the Growth Performance of Indigenous and Exotic Banana Clones in the Semi-Arid Climate of South-Western Agro-Ecological Zone of Uganda
}

\author{
Robert Muzira ${ }^{1 *}$, Laban Turyagyenda ${ }^{2}$, Peace Kankwatsa1, Maggiore Kyomugisha1, \\ Hellen Mutenyo ${ }^{1}$, Steven Natuha ${ }^{1}$ \\ ${ }^{1}$ National Agricultural Research Organization, Mbarara-ZARDI, Uganda \\ ${ }^{2}$ National Agricultural Research Organization, Ngetta-ZARDI (Lira), Uganda \\ Email: ${ }^{*}$ rmuzira@yahoo.com, labanturyagyenda@gmail.com,kankwatsap@gmail.com,maggiore2011@gmail.com, \\ mutenyoh@gmail.com, natuhasteven@yahoo.com
}

How to cite this paper: Muzira, R., Turyagyenda, L., Kankwatsa, P., Kyomugisha, M., Mutenyo, H. and Natuha S. (2020) Exploration of the Growth Performance of Indigenous and Exotic Banana Clones in the Semi-Arid Climate of South-Western Agro-Ecological Zone of Uganda. Open Access Library Journal, 7: e5809.

https://doi.org/10.4236/oalib.1105809

Received: September 23, 2019

Accepted: February 23, 2020

Published: February 26, 2020

Copyright $\odot 2020$ by author(s) and Open Access Library Inc.

This work is licensed under the Creative Commons Attribution International License (CC BY 4.0).

http://creativecommons.org/licenses/by/4.0/

\begin{abstract}
On station experimental trial on the growth performance and resistance against black sigatoka of the indigenous and exotic banana clones were evaluated at Mbarara Zonal Agricultural Research and Development Institute. The experiment composed of 11 indigenous and 3 exotic banana clones planted at $3 \times 3 \mathrm{~m}$, and replicated three times in three blocks, was laid in a Complete Randomized Block Design. Data on banana growth parameters and susceptibility to black sigatoka were collected in the $3^{\text {rd }}$ and $4^{\text {th }}$ crop cycles. Both the indigenous and exotic banana clones exhibited high growth and yield potentials in the semi-arid conditions of the south-western agroecological zone of Uganda. Kabucuragye and Williams had significantly $(\mathrm{p}<0.05)$ taller and shorter pseudostems compared to other banana clones, respectively. FHIA 17 and FHIA 23, exhibited the largest pseudostem girths of $84.97 \mathrm{~cm}$ and $75.4 \mathrm{~cm}$, respectively. Also, the highest number of leaves was observed with the same banana clones: FHIA 17 (12.8) and FHIA 23 (12.6), indicating that they had the highest growth vigor. Mporogoma exhibited significantly ( $\mathrm{p}$ $<0.05$ ) more fingers on hands, in turn leading to significantly higher bunch weights compared to other indigenous banana clones. Nonetheless, FHIA 17 and FHIA 23, had significant superior bunch weights. Exotic and Mporogoma indigenous clones were most susceptible to black sigatoka among all the banana clones.
\end{abstract}




\section{Subject Areas}

Agricultural Science

\section{Keywords}

Banana, Black Sigatoka, Clones, Growth, Yield

\section{Introduction}

Uganda is ranked among 20 top countries in the world in banana production and consumption [1]. Annual consumption of banana in Uganda is $1 \mathrm{~kg}$ per person per day, which is considered the highest on the global scale [2]. Banana takes the largest cultivable area among the agricultural crops in Uganda and occupies over $75 \%$ of the arable area in the south-western Uganda [3]. Among small-scale farmers, banana is grown on small fields of less than $0.5 \mathrm{ha}$, and considered the main source of household food and income security [3].

In Uganda, banana is majorly consumed as food after steaming or roasting. Nonetheless, it is also consumed as fruit in form of desert or processed into flour, juices and wines [4].

Most banana clones preferred by farmers are indigenous to the East African highlands that are considered to be one of the global centers for banana biodiversity. Nonetheless, new clones have been integrated into the existing banana farming systems because of their comparable tolerance to pests and diseases [5]. While the biological diversity of bananas in Uganda is well understood in terms of taxonomic, use, genetics, and variety characteristics [6], there is limited information concerning their comparable growth performance even within the banana farming systems in the south-western agro-ecological zone of Uganda. Therefore, an on-station experiment was established at Mbarara Zonal Agricultural Research and Development Institute to investigate the growth performance of ten indigenous and three exotic banana clones and their levels of tolerance against black sigatoka disease under the semi-arid conditions of the south-western agro-ecological zone of Uganda.

\section{Materials and Methods}

\subsection{Study Site}

The experiment was conducted on station at Mbarara Zonal Agricultural Research and Development Institute, located in the South-Western Agro-Ecological Zone of Uganda (Figure 1), which is characterized with the semi-arid conditions. The site is 1433 meters above sea level and receives an average annual rainfall of $1373 \mathrm{~mm}$ in bimodal distribution that occurs in March-May and September-December. The least and highest amounts of rainfall occur in January and April, with the average precipitation of 33 and $183 \mathrm{~mm}$, respectively. The temperatures are highest and lowest in February and August with $24.1^{\circ} \mathrm{C}$ and 


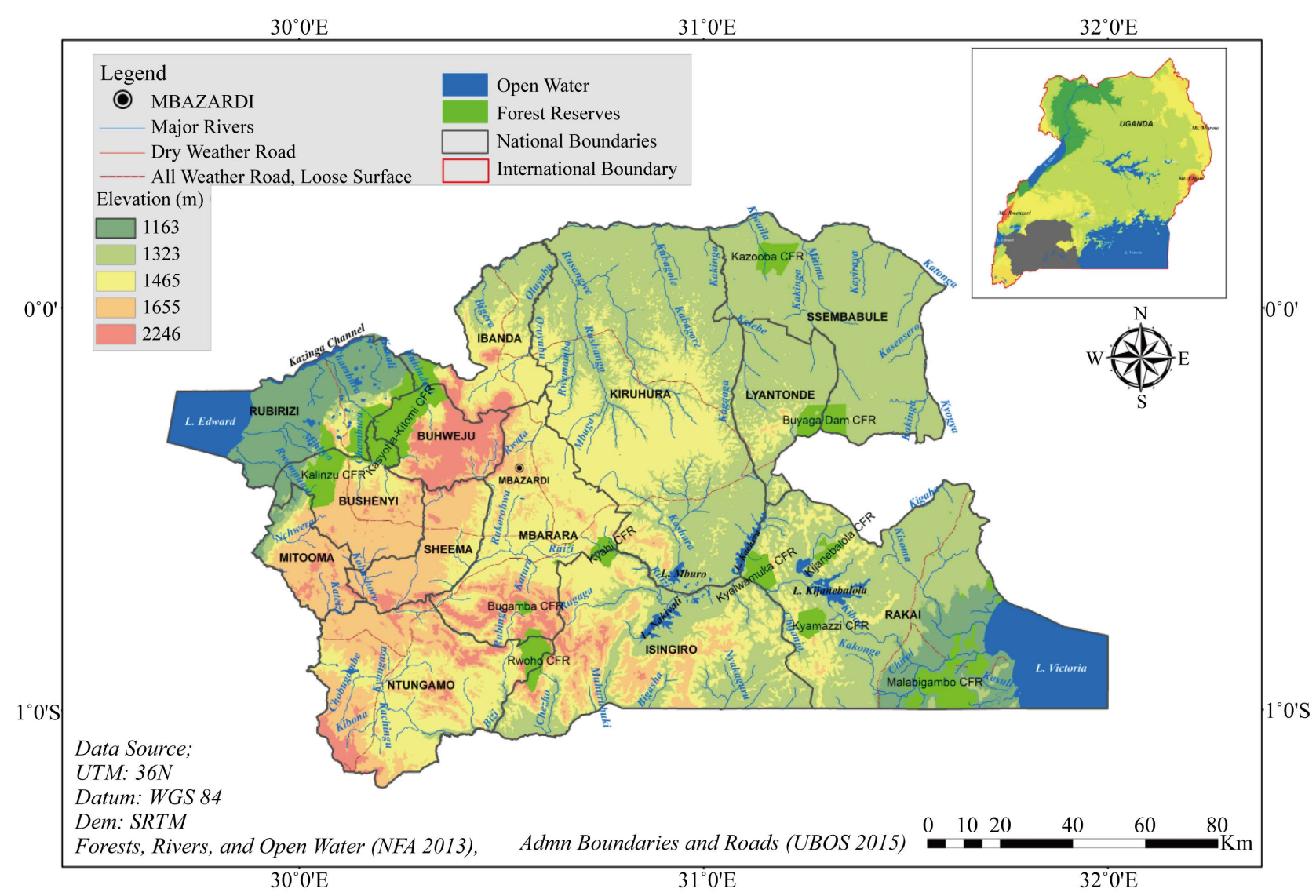

Figure 1. Physical features and location of the South-Western Agro-Ecological Zone of Uganda (Source: NARO-Mbarara).

$21.6^{\circ} \mathrm{C}$, respectively [7]. Evapotranspiration of the area $(1300-1450 \mathrm{~mm})$, is lower than most of the surrounding areas that are close to water bodies. During the study period, the experimental site had peaks of rains in April and November, while July had the lowest monthly precipitation (Figure 1). The area is predominated by ferrallitic soils, which are mainly sandy loams and sandy clay loams with good drainage [8].

The on-station experimental site had sandy clay loams and at the onset of the experiment the soil $\mathrm{pH}$ of 5.0. Total soil organic matter and nitrogen were 3.4\% and $0.18 \%$, respectively. On the other hand, soil extractable phosphorus and exchangeable potassium were 9.88 and 306 ppm, respectively. Soil nitrogen and phosphorus were below critical levels for optimum banana growth and hence, banana stools were applied with farmyard manure at the beginning of every season to offset the deficits (Figure 2).

\subsection{Experiment Establishment}

The experiment was composed of 11 and 3 indigenous and exotic banana clones, respectively. Indigenous banana clones were those commonly grown on farm as mosaic (Atwalira, Entaragaza, Enyeru, Kabucuragye, Kibuzi, Kisansa, Lumenyamagali, Mpologoma, Ntika, Rwambarara and Siira) in the south-western agro-ecological zone of Uganda. Exotic banana clones were FHIA 17, FHIA 23 


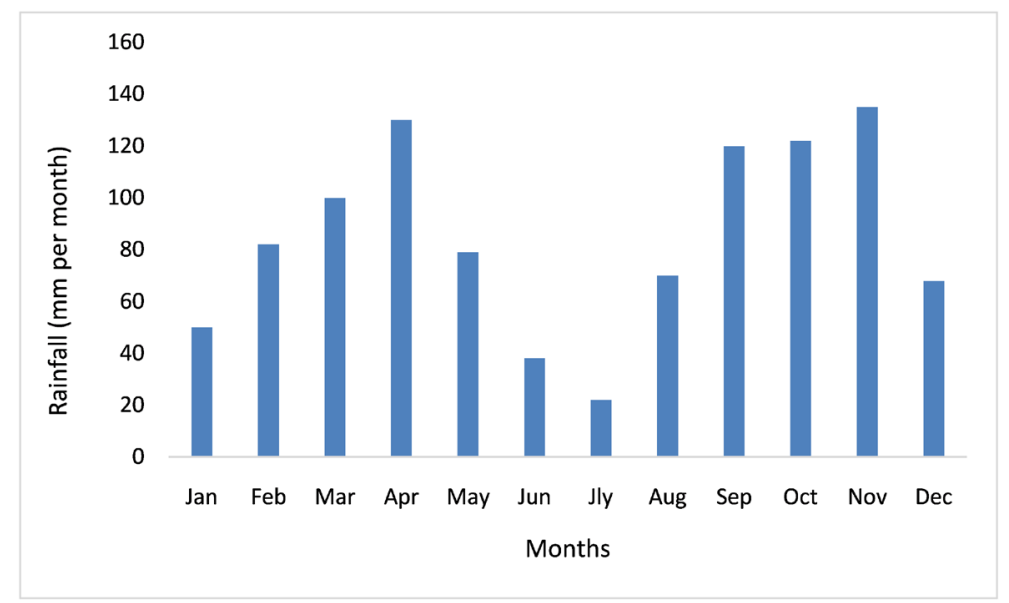

Figure 2. Total monthly rainfall during study period (Source: Mbarara local government).

and Williams, that are gradually getting integrated into the existing banana cropping systems in smallholder farms. The trial was established from banana suckers of uniform size obtained from a clean mother garden earlier established for banana variety multiplication.

The land was well ploughed, harrowed, leveled and divided into three blocks with plots of $9 \times 9 \mathrm{~m}$ size; spacing between plants was $3 \times 3 \mathrm{~m}$ with 3 replications and 16 banana plants per plot. However, effective plot size for plant sampling, which was done in the $3^{\text {rd }}$ and $4^{\text {th }}$ crop cycles was $3 \times 3$ m with 4 banana mats. The banana suckers were planted in a Randomized Complete Block Design at the beginning of the long rain season (September-December), and it solely depended on rains. The suckers were placed upright in holes of $40 \mathrm{~cm}$ in width, length and depth and covered with a $10 \mathrm{~cm}$ layer of topsoil mixed with $10 \mathrm{~kg}$ of composted goats manure. Shallow weeding was regularly done with a hand hoe. Trenches were constructed between blocks as well as on top and below the experimental field to control surface runoff and soil erosion. Banana mats were regularly earthed up during weeding and furadan used to control banana nematodes and weevils. Desuckering and removal of water suckers except two suckers with their mother plant was regularly done before and during the onset of data collection. The banana plants were regularly de-leafed of old and collapsed leaves before and during the data collection. The entire field was regularly mulched with elephant grass and banana plant remains (leaves and pseudostem) that were uniformly laid to control weed growth and moisture loss. The male flower bunds were removed with forked stick to control banana bacterial that could be spread by bees.

\subsection{Data Collection}

Data collection was done at flowering and harvesting of mature banana bunch. Pseudostem height was measured by considering the length of $5 \mathrm{~cm}$ from the base of the mulch-free psedostem to the point of the upper-most two youngest 
leaves. This was measured with a tape supported with a long stick. Pseudostem girth was measured at $15 \mathrm{~cm}$ above the level of soil surface, using tape-measure. Standing leaves and those with signs of black sigatoka were counted.

The mature banana bunches were harvested when color of the fingers had changed from dark green to light green. At this stage the following data were captured (i) bunch weight; (ii) number of hands; and (iii) number, lengths, girths and weights of fingers of the middle hand. A stalk length of approximately $10 \mathrm{~cm}$ was left with the bunch to facilitate handling and weighing using a spring balance. The hands of the banana bunch were removed with a help of a sharp knife and counted. Average number of banana of well-developed fingers on each hand was determined by dividing total number of fingers by number of hands on the banana bunch. Finger lengths were determined as averages for fingers from the center of both outer and inner rows of the second, fourth and sixth hands from the proximal ends of bunch. Average lengths were assessed by measuring the length of the convex surface from the tip to the pedicel and that of the concave surface of each finger.

\subsection{Data Analysis}

The collected data was entered into micro-soft Excel for cleaning, management and storage. The data was later exported into R statistical program and subjected to the Analysis of Variance. Tukey multiple comparison of means at $95 \%$ family-wise confidence level and kruskal test were used to assess levels of significance of the measured parameters among the different banana clones.

\section{Results and Discussion}

\subsection{Plant Height and Pseudostem Girth}

Plant heights varied depending on the banana clones [9]. Kabucuragye was significantly $(\mathrm{p}<0.05)$ taller than both the indigenous and exotic banana clones (Figure 3). The plant height is one of the morphological characteristics that is used distinguishes banana clones [6]. Hence, Kabucuragye could easily be distinguished from all other clones due to its towering height.

Williams was the shortest banana clones, and its height was significantly shorter than all the other banana clones. While the FHIA exotic banana clones were not significantly different in terms of height from each other, they were significantly taller than Williams, which was also an exotic banana clone. The short height of Williams made it easily distinguished from other banana clones. Williams banana clones are characterized by short to medium heights [10].

There are different genomic distances controlling pseudostem heights of the indigenous and exotic banana clones [11]. The indigenous banana clones are taller than the exotic banana clones. Plant height in banana is closely related to foliar growth, since it consists of overlapping leaf sheaths. Kabucuragye has the longest leaf sheaths compared to other banana clones.

Pseudostem girth for the FHIA banana clones was significantly larger than all 


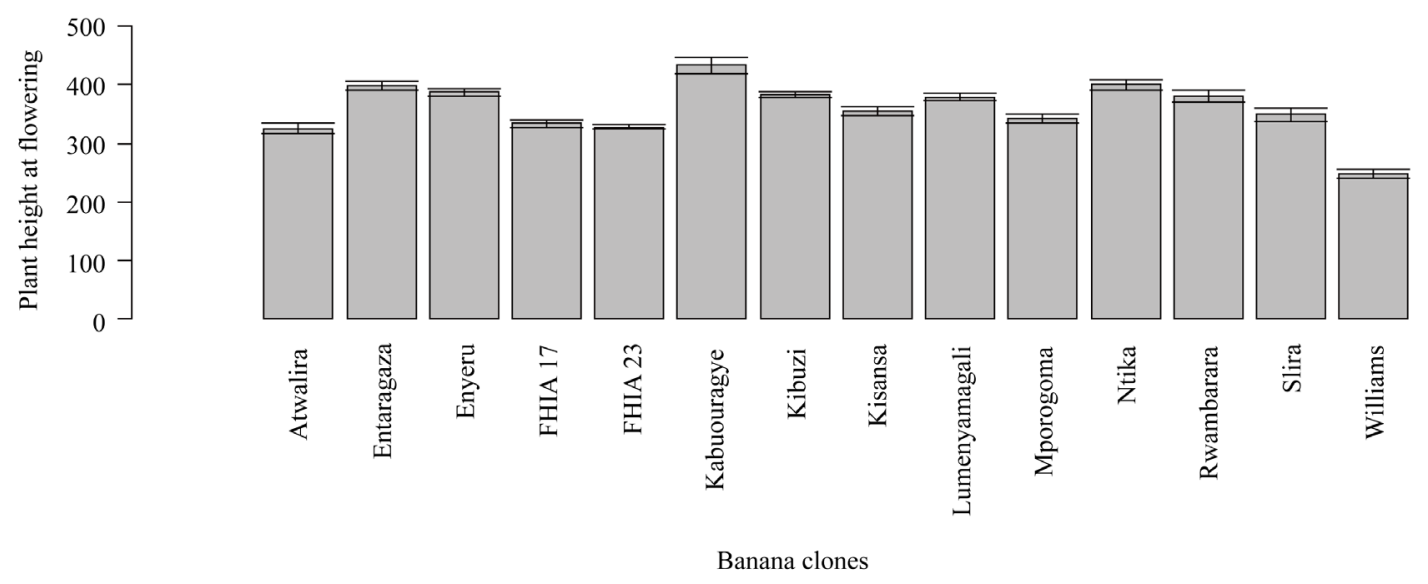

Figure 3. Variation plant heights $(\mathrm{cm})$ with the banana clones.

the other banana clones (Figure 4). The size of the pseudostem is also related to foliar growth, and it is one of the morphological characteristics used to distinguish banana clones [10]. FHIA banana clones had shorter leaf sheaths but many compared to other banana clones. The large size of pseudostem girths of FHIA 17 and FHIA 23, is one of the phenotypic characteristic that is often to distinguish them from the indigenous clones [10]. Kisansa, the indigenous banana clone, had the smallest pseudostem girth among the banana clones, though it was not significantly different from Atwalira, the indigenous banana clone. The size of the pseudostem girth also indicates, the amounts of soil nutrients and water required to support banana growth [12]. It also indicates plant growth vigor [13]. Hence, the FHIA banana clones have higher plant vigor and potential for higher volumes of soil water and nutrients uptakes compared to the indigenous banana clones.

\subsection{Number of Functional Leaves and Suckers}

Exotic banana clones had significantly higher number of banana functional leaves than the indigenous clones (Figure 5). Among the indigenous banana clones, it was Mporogoma that had the highest number of the banana functional leaves, which was significant from the rest of the indigenous banana clones. Exotic banana clones and Mporogoma indigenous clone are known to bear large bunches of banana fruits, synonymous with number of functional leaves [9].

FHIA 17 and FHIA 23, the exotic banana clones, had significantly higher number of suckers compared to all other banana clones (Figure 6). All exotic banana clones had significantly different numbers of suckers, with FHIA 23, having the highest number of suckers. This indicated that exotic banana varieties were more prolific than the indigenous banana clones, and hence may require more frequent desuckering compared to the indigenous banana clones. This calls for regular removal of suckers before they become too large since they may reduce radiation to the ground and drain assimilation from the parent plant. This in turn would reduce banana bunch size due to intra and inter-mat competition [14]. 


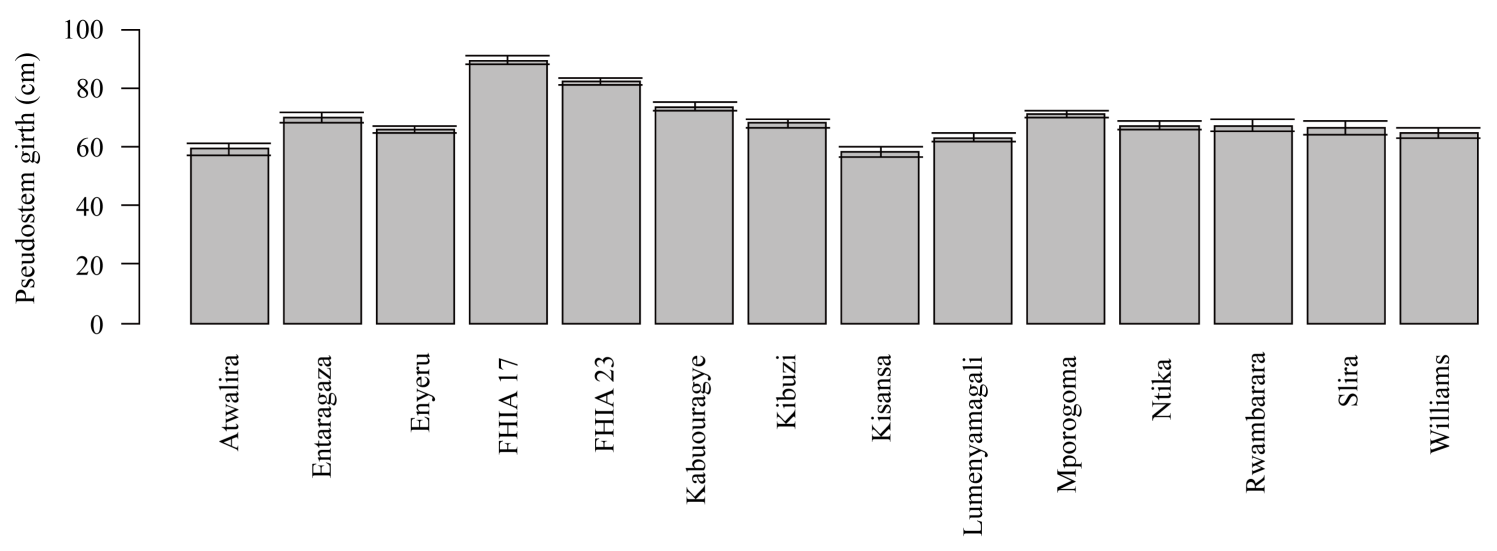

Banana clones

Figure 4. Variation girth of pseudostems with the banana clones.
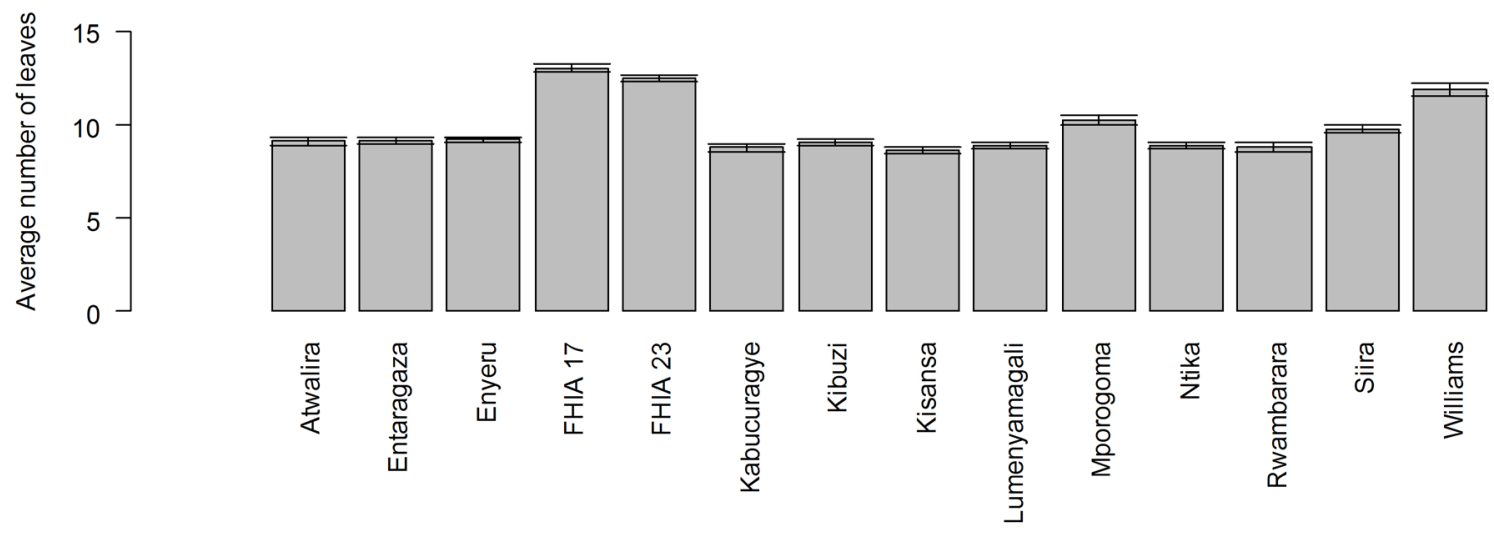

Banana clones

Figure 5. Variation of number of functional leaves with the banana clones.

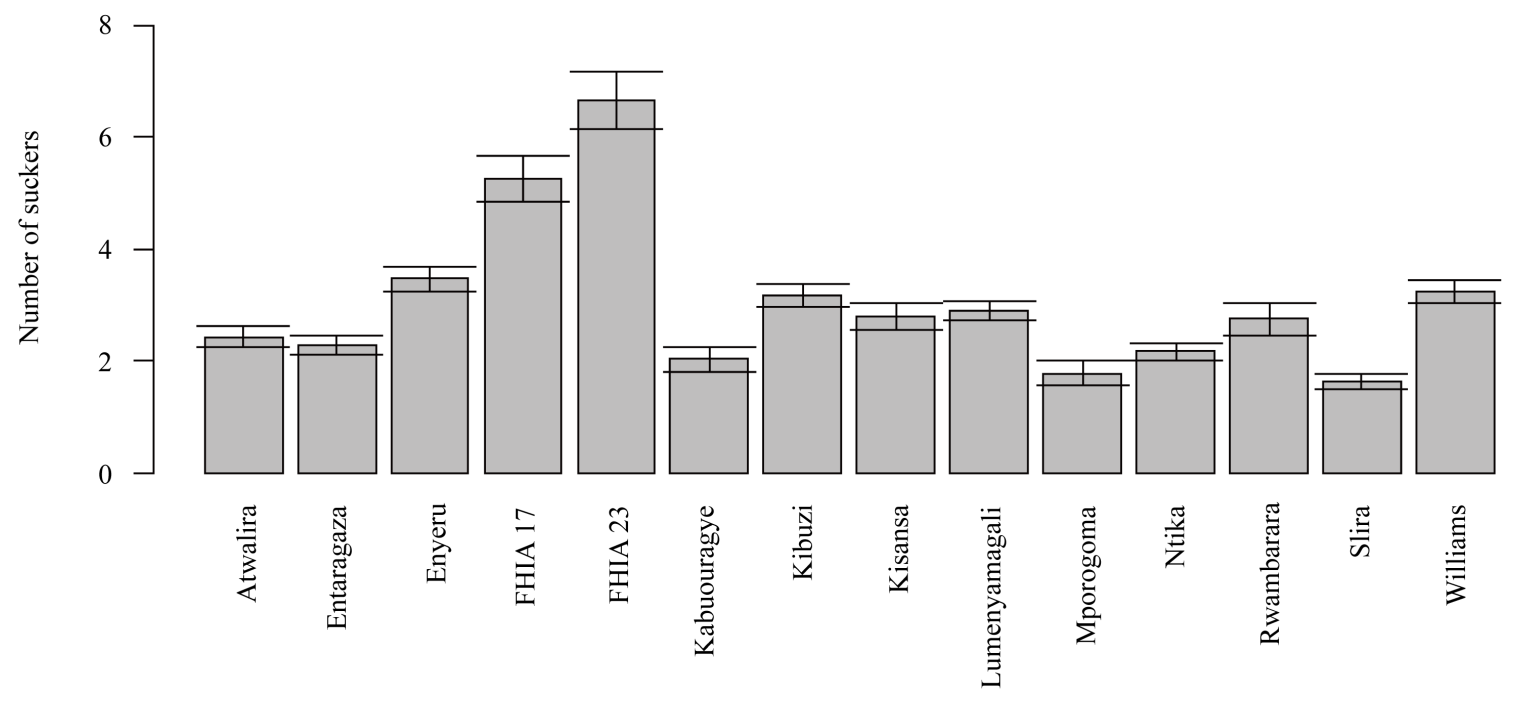

Banana clones

Figure 6. Variation in number of suckers with banana clones. 


\subsection{Bunch Weight and Its Attributes}

Exotic banana clones had lower number of fingers per cluster compared to most indigenous banana clones (Figure 7). There were no significant differences in number of fingers per cluster for the exotic banana clones. Williams had significantly lower number of finger per cluster compared to Siira, Mprogoma, Lumenyamagali, Kibuzi, Rwambarara and Enyeru. Entaragaza, Kabucuragye and Kisansa had the lowest number of fingers per cluster among the indigenous banana clones.

Kisansa had the longest finger lengths that were significantly different from the other banana clones (Figure 8). On the other hand, Ntika had the shortest finger lengths compared to all other banana clones. However, its finger lengths were not significantly different from other clones, other than FHIA 17, FHIA 23 , Mporogoma, Kisansa and Lumenyamagali.

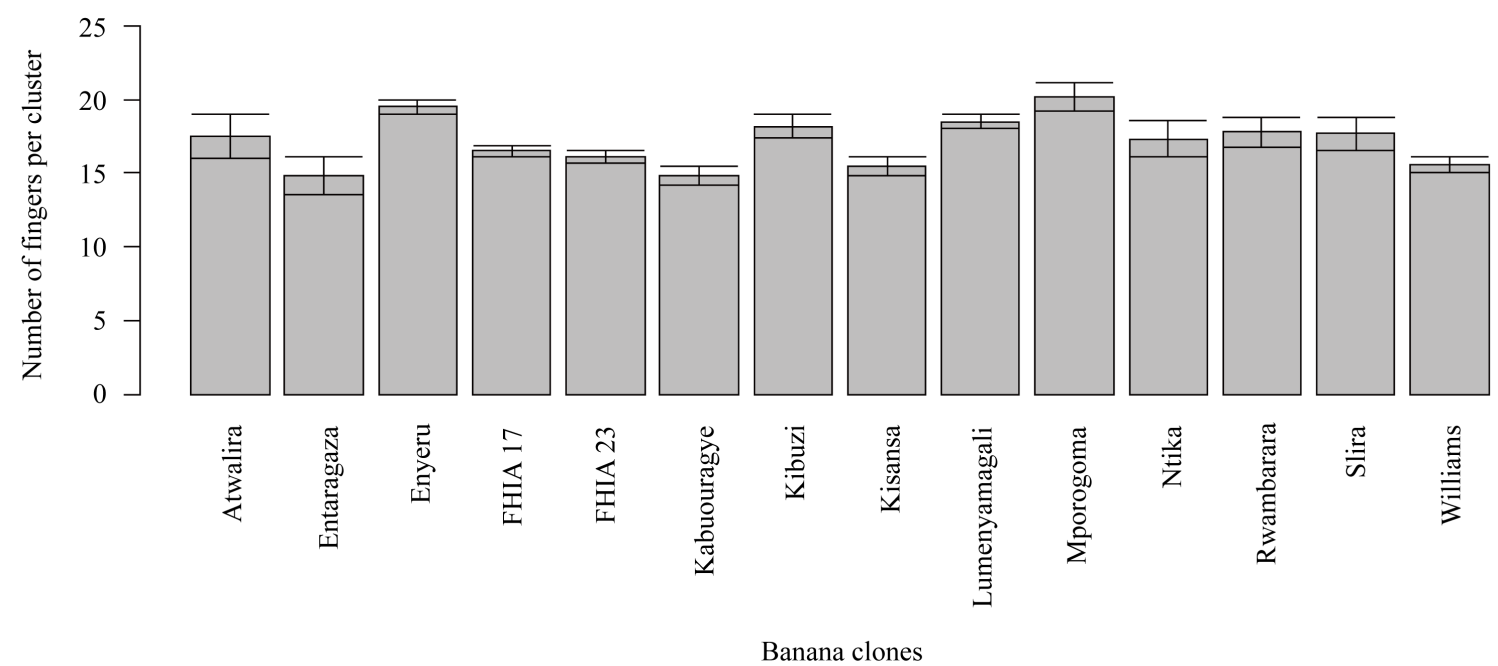

Figure 7. Variation in number of fingers per cluster with banana clones.

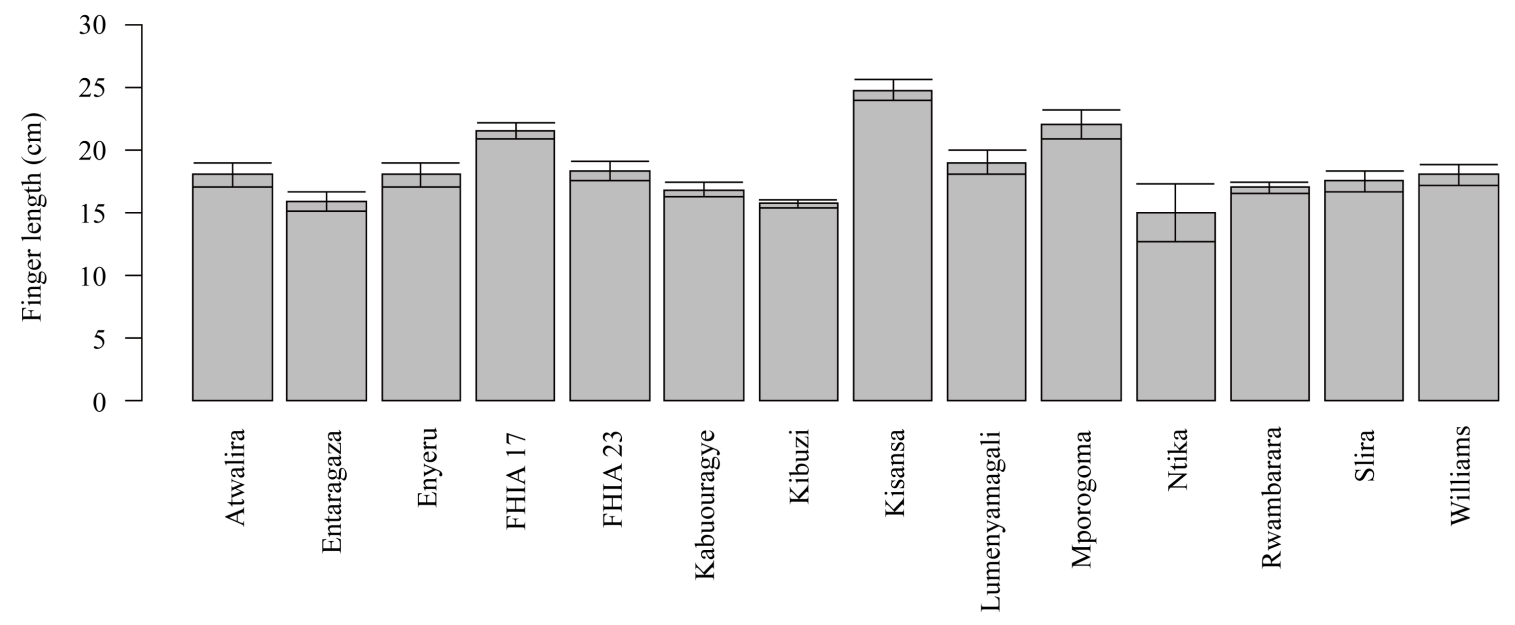

Banana clones

Figure 8. Variation in finger length with the banana clones. 
FHIA 17, FHIA 23, Mporogoma and Kisansa had finger of higher weights compared to other banana clones (Figure 9). Nonetheless, Mporogoma had fingers that were significantly higher than all the other banana clones, other than Lumenyamagali, Kisansa, FHIA 17 and FHIA 23.

Ntika and Rwambarara exhibited fingers of lowest weights among all the banana clones. Other than Ntika, finger weights of Rwambarara were significantly lower than all the other banana clones.

\subsection{Susceptibility to Black Sigatoka}

Black sigatoka was mostly exhibited on FHIA 17, FHIA 23, Williams and Mporogoma banana clones (Figure 10). On the other hand, Ntika and Kisansa, were least susceptible to black sigatoka. These two clones could provide genes for reducing susceptibility to black sigatoka, highly exhibited in other banana clones. Exotic clones as reported elsewhere, showed high susceptibility to black sigatoka compared to most local banana clones [15].

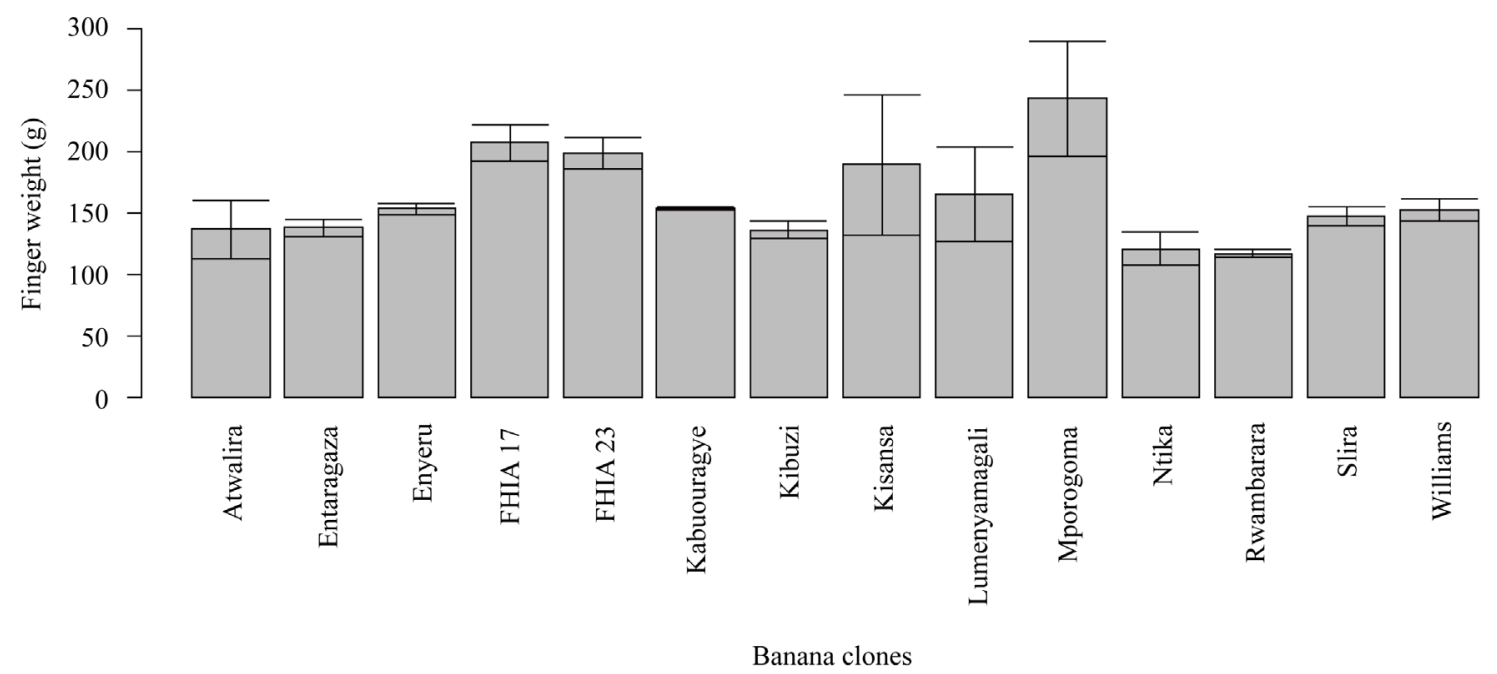

Figure 9. Variation of figure weights with banana clones.
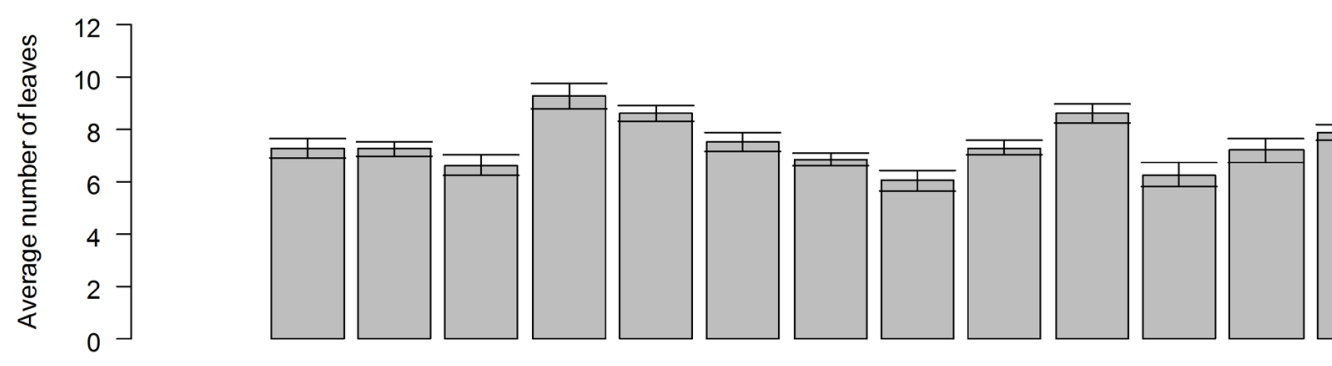

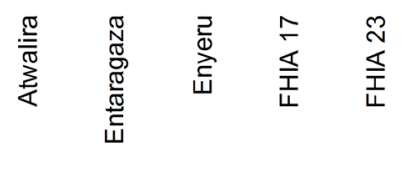

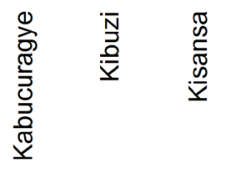
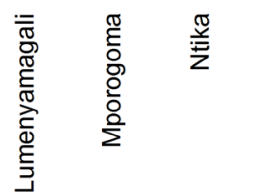

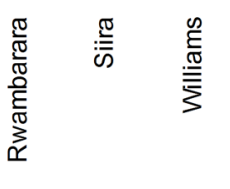

Banana clones

Figure 10. Variation in number of black sigatoka affected functional leaves with banana clones. 


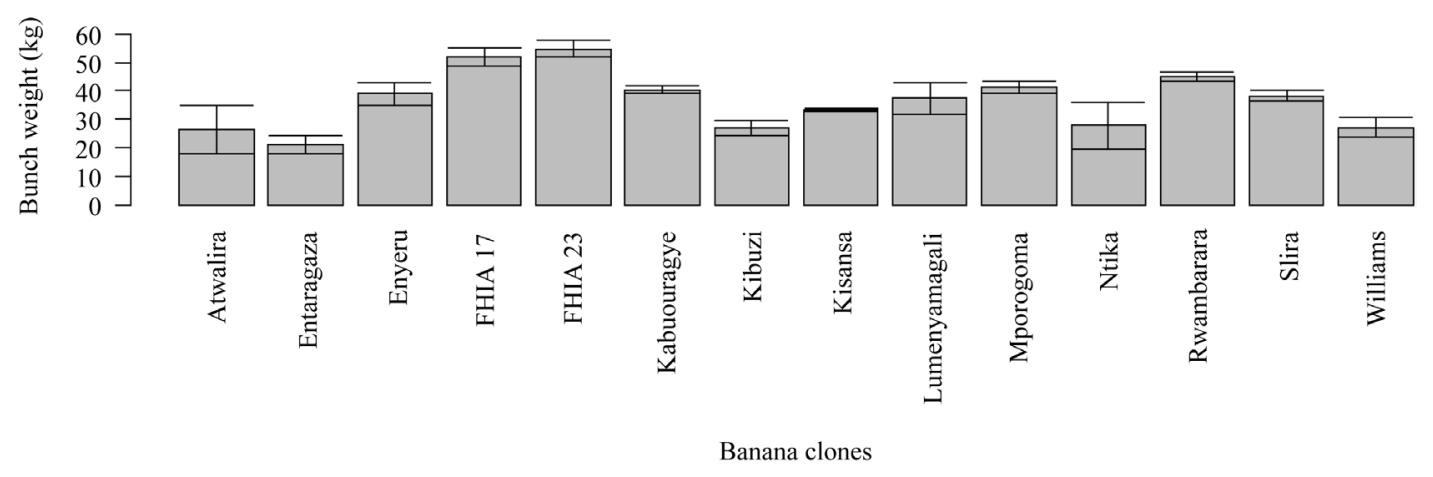

Figure 11. Variation in bunch weight with banana clones.

Other than Williams, exotic banana clones (FHIA 17 and FHIA 23) had significantly superior weights compared to the indigenous banana clones (Figure 11) as also reported elsewhere [9]. Banana bunches from Mporogoma, Siira, Rwambarara, Entaragaza and Atwalira, expressed higher bunch weights among the indigenous banana clones. These five clones have high potential of continuing to supply the needed diet to the growing population in the semi-arid zone of the south-western agro-ecological zone of Uganda [14]. Banana are cheap source of energy, good sources of vitamins $\left(A, B_{6}\right.$, and $C$ ), minerals (especially $K$, and small amounts of $\mathrm{P}, \mathrm{Mg}$ and $\mathrm{S}$ ), carbohydrates and fibers [16]. Williams, had significantly lower yields than most of the indigenous banana clones (Siira, Rwambarara, Mporogoma, Kisansa, Kabucuragye and Enyeru). The FHIA 17 and FHIA 23 are often used as desserts and if left to ripen they could provide over $19 \%$ sugars (sucrose, glucose and fructose) as reported by [17].

\section{Conclusions}

All the banana clones evaluated were able to grow in the semi-arid conditions and expressed their genetic potential differences. Nonetheless, FHIA 17 and FHIA 23, expressed higher bunch weights among all the clones. Among the indigenous banana clones; Rwambara, Mporogoma, siira, Kabucuragye, Lumenyamagali and Enyeru, expressed superior bunch weights, even compared with Williams, the exotic banana clone.

All the exotic banana clones were more susceptible to black sigatoka compared to the indigenous banana clones. Ntika and Kisansa enyeru, expressed higher tolerance to black sigatoka compared to other banana clones. Hence, they could be planted in hot spot areas where banana production is declining due to black sigatoka.

\section{Conflicts of Interest}

The authors declare no conflicts of interest regarding the publication of this paper.

\section{References}

[1] FAO (Food and Agriculture Organization of the Nations) (2015) Country Situation 
and Role of Agriculture: Country Fact Sheet on Food and Agriculture Policy Trends. 6.

[2] FEWS NET (Famine Early Warning Systems Network) (2017) Uganda Staple Food Staple Food Market Fundamentals.

[3] UBOS (2010) Uganda Census of Agriculture Crop Area and Production Report, Vol. 4.

[4] Kiiza, B., Abele, S. and Kalyebara, R. (2004) Market Opportunities for Ugandan Banana Products: National, Regional and Global Perspectives. No. February, 743-749.

[5] Albertson, E. and Albertson, E. (2016) Adopting New Banana Varieties in Uganda: The Role of Gender and Head of Household Status.

[6] Atom, A.D., Lalrinfela, P. and Thangjam, R. (2015) Genome Classification of Banana Genetic Resources of Manipur Using Morphological Characters. Science Vision, 15, 189-193.

[7] World Weather Channel (2019) World Weather Online. https://www.worldweatheronline.com

[8] Isabirye, M., Mwesige, D., Ssali, H., Magunda, M. and Lwasa, J. (2004) Soil Resource Information and Linkages to Agricultural Production. Uganda Journal of Agricultural Sciences, 9, 215-221.

[9] Bhende, S.S., Kurien, S. and Sesha Iyer, K. (2018) Grouping of Banana Clones Based on Genomic Groups, Ploidy, and Seasons of Planting for Sucker Production in $\mathrm{Mu}$ sa spp. International Journal of Food Science, 18, 45-67. https://doi.org/10.1080/15538362.2017.1377668

[10] Kepler, A.K. and Rust, F.G. (2011) The World of Bananas in Hawai'i: Then and Now. Traditional Pacific and Global Varieties, Cultures, Ornamentals, Health and Recipes. Pali-O-Waipi'o Press, Haiku.

[11] Hippolyte, I., et al. (2010) A Saturated SSR/DArT Linkage Map of Musa acuminata Addressing Genome Rearrangements among Bananas. BMC Plant Biology, 10, Article No. 65. https://doi.org/10.1186/1471-2229-10-65

[12] Oman, N. (2009) Effect of NPK Fertilizer on Growth and Yield of Banana in Northern Oman. Journal of Horticulture and Forestry, 1, 160-167.

[13] Miele, A. and Rizzon, L.A. (2017) Rootstock-Scion Interaction: 2. Effect on the Composition of Cabernet Sauvignon Grape Must. Revista Brasileira de Fruticultura, 39, e-434. https://doi.org/10.1590/0100-29452017434

[14] Musa, D., et al. (2013) Effect of Fertilizer Insertion in the Harvested Mother Banana Plant Pseudostem (Musa AAA Simmonds). Agronomia Colombiana, 31, 103-111.

[15] Ploetz, R.C. (2001) Black Sigatoka of Banana. The Plant Health Instructor.

[16] Hapsari, L. and Lestari, D.A. (2016) Fruit Characteristic and Nutrient Values of Four Indonesian Banana Cultivars (Musa spp.) at Different Genomic Groups. Agrivita Journal of Agricultural Science, 38, 303-311. https://doi.org/10.17503/agrivita.v38i3.696

[17] Sakyi-Dawson, E., Asamoah-Bonti, P. and Amponsah Annor, G. (2008) Biochemical Changes in New Plantain and Cooking Banana Hybrids at Various Stages of Ripening. Journal of the Science of Food and Agriculture, 88, 2724-2729. https://doi.org/10.1002/jsfa.3399 